\title{
Bearing Capacities of Backfilled Soil from Maswtest: a Quick and Convenient Methodology
}

\author{
Arkaprabha Chattopadhyay*, Debdeep Sarkar and Sekhar Chandra Dutta \\ Department of Civil Engineering, IIT(ISM) Dhanbad, India
}

Submission: December 12, 2017; Published: February 28, 2018

*Corresponding author: Arkaprabha Chattopadhyay, Department of Civil Engineering, IIT(ISM) Dhanbad, Jharkhand, India, Dhanbad-826001,

Email: arkaprabhachattopadhyay94@yahoo.com

Keywords: Bearing capacities; Backfilled soil

\section{Introduction}

\section{Soil characteristics through multichannel analysis of surface waves (Masw):}

First introduced in GEOPHYSICS (1999), the multichannel analysis of surface waves (MASW) method is one of the popular seismic survey methods evaluating the elastic condition (stiffness) of the ground for geotechnical engineering purposes particularly for highly heterogeneous soil like mine backfill. The demonstration of such a convenience is presented in $t$ is short article for the sake of information to the community. MASW first measures seismic surface waves generated from various types of seismic sources, such as sledge hammer or automatic drop hammer. It further analyses the propagation velocities of those surface waves. Then finally variations of shear-wave velocity $\left(V_{s}\right)$ below the surveyed area are obtained. Shear-wave velocity $\left(V_{s}\right)$ is one of the elastic constants and closely related to Young's modulus. Under most circumstances, $\left(V_{s}\right)$ is a direct indicator of the ground stiffness which is used to derive load-bearing capacity. After a relatively simple procedure, final information is provided in 1-D, 2-D, and 3-D formats.

\section{MASW Test}

The test was conducted at Jagannath colliery (Talcher, Orissa, India, Latitude- 20057'50.021", Longitude- 85०07'57.021") near a bore hole already the bearing capacity through which have been tested. 24 Geophones were set across bore holeat a distance of $1 \mathrm{~m}$ apart from each other, 12 on either side of the borehole. The last geophone was connected to a trigger and the signal is induced to it by hammering. The other geophones were connected to the receivers which pass on the acquired signals due to hammering, to the geophones. The geophones then pass on the signals to the controller (installed in laptop). This controller records the signals, analyses and generates outputs accordingly. The acquisition was carried out in a compact-sized 24 channel seismograph with a 24 bit data acquisition board and USB interface for external PC.

\section{Analysis of the acquired data}

The analysis after performing the test and acquisition of the relevant data was carried out in the software winMASW Version 7.2 which produced the following results (Figure $1 \& 2$ ).

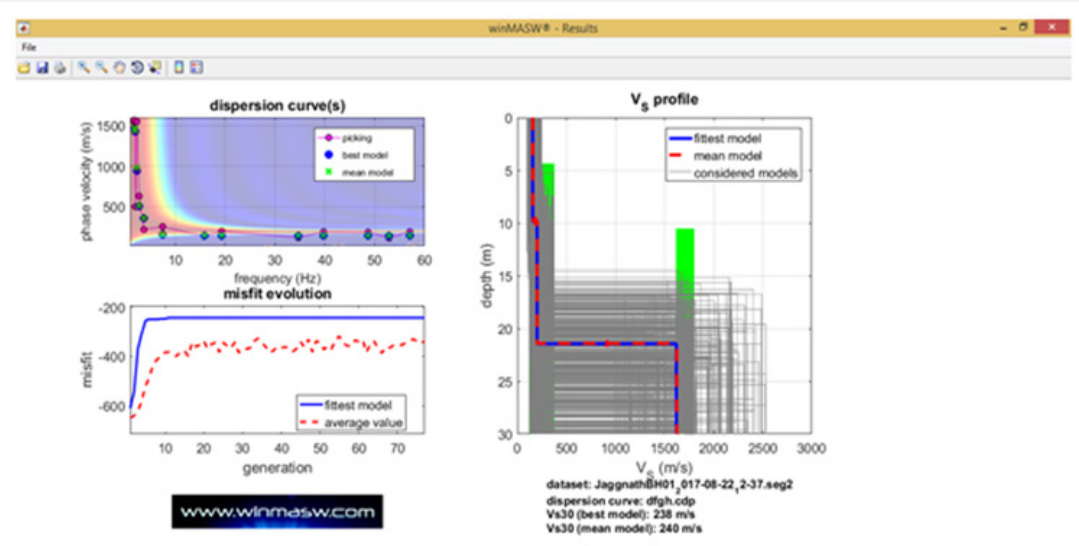

Figure 1: Source- winMASW analysis software. 


\section{Civil Engineering Research Journal}

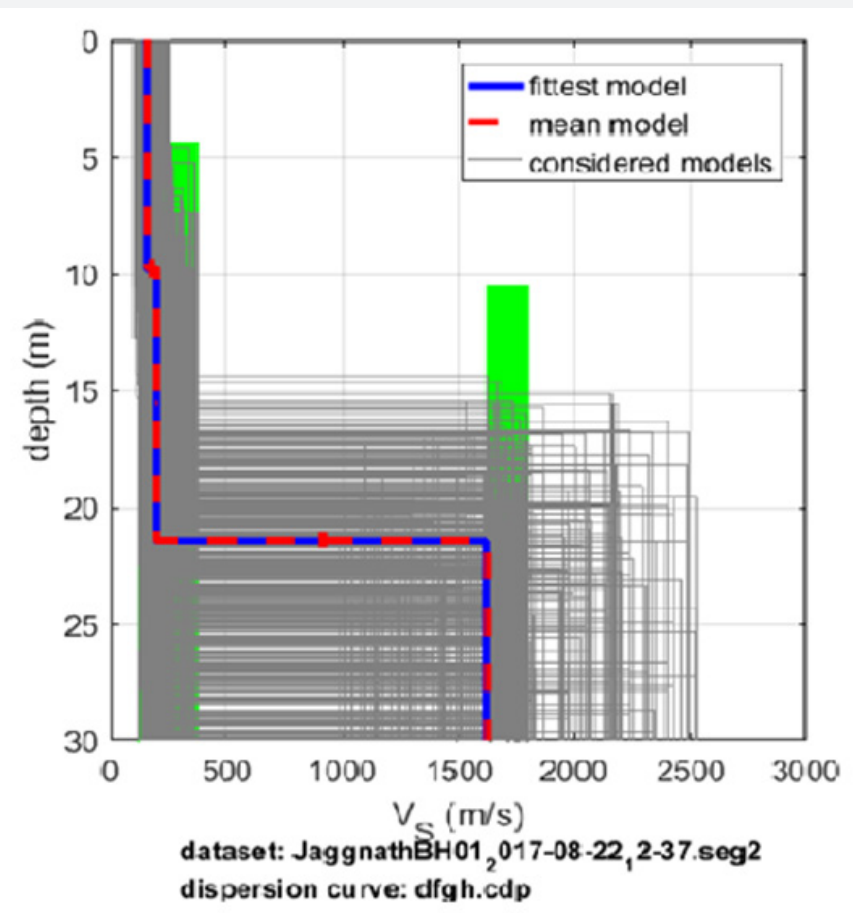

Figure 2: Dispersion curve of depth versus shear wave velocity (Source-winMASW analysis software).

$\left(V_{s}\right)$ Profile (Enlarged)

After obtaining the shear wave velocity, the elasticity modulus of the soil was obtained from appropriate formulae. Further, the allowable bearing capacity of soil was obtained by an indirect relationship utilizing the modulus of sub grade reaction of soil. The adopted procedure is explained and enumerated as follows.

The density of the soil at Jagnnathpur site previously obtained was $\rho 2610 \mathrm{~kg} / \mathrm{m}^{3}$ (obtained from specific gravity test). Hence density, $=2610 \mathrm{~kg} / \mathrm{m}^{3}, \boldsymbol{U}=0.25$. Further, from MASW dispersion curve, shear velocity $\left(V_{s}\right)$ obtained at $3 \mathrm{~m}$ depth is $155 \mathrm{~m} / \mathrm{s}$. It is known that shear wave velocity $V_{s}=\sqrt{G} / \rho$ where $G$ is the shear modulus. Hence, substituting the corresponding values the shear modulus is obtained as $G=\rho V_{s}^{2}=62.7 \times 10^{6} \mathrm{~N} / \mathrm{m}^{2}$. Further, modulus of elasticity is obtained as ${ }_{G} G=\rho V_{s}^{2}=62.7 \times 10^{6} \mathrm{~N} / \mathrm{m}^{2}$

From the following equation [1], modulus of sub grad $k_{s}=E_{s} / B\left(1-v^{2}\right)^{=16.72 \times 10^{6} \mathrm{~N} / \mathrm{m}^{3}}$. Again, from the same literature [1], another empirical relation between modulus of sub grade reaction and allowable bearing capacity can be obtained as

$$
k_{s}=40 \times F \cdot O \cdot S \times Q_{a}
$$

From the above equation, considering a Factor of Safety (F.O.S) of 3 the allowable bearing capacity is obtained as $Q_{a}=13.93 \mathrm{t} / \mathrm{m}^{2}$. On the other hand, the SPT test conducted in this region produced an SPT value of . As the width of footing > $4 \mathrm{ft}$, allowable bearing capacity can be given by the equation as follows [2].

$$
Q_{a}=N / 4[(B+1) / B]^{2} / K \text {, where } K=1+0.33(\mathrm{D} / \mathrm{B})<=1.33 \text {; where }
$$

is the depth from ground level to bottom of the footing in feet; is the width of footing in feet. Hence, substituting the corresponding numerical values, $=1+0.33(9.84 / 32.81)$ which gives the value as 1.10 and the allowable bearing capacity is obtained as $\left.{ }_{Q_{a}}={ }^{14 \times[(32.81+1) / 32.81}\right] /(4 \times 1.10)=16.18 \mathrm{t} / \mathrm{m}^{2}$.

\section{Conclusion}

Comparing the bearing capacities obtained from SPT test and MASW analysis of Jagannath colliery it can be inferred that they are more or less close to each other $\left(16.18 \mathrm{t} / \mathrm{m}^{2}\right.$ and $13.93 \mathrm{t} / \mathrm{m}^{2}$ ) which ascertains the accuracy of the tests. Further, conducting test by MASW is less hazardous as no digging or previous preparation is needed and the test can be carried out more quickly at more than one places within a day. Thus, it may be extremely helpful for deciding the characteristics of heterogeneous soil.

\section{Acknowledgement}

The present article is a small part of the activity of Coal S\&T project bearing a number EE46 sanctioned by Ministry of Coal, Government of India. Financial support rendered by them for MASW is greatly acknowledged.

\section{References}

1. Bowles JE (1968) Foundation Analysis and Design (1 $1^{\text {st }}$ edn). McGrawHill.

2. Bowles JE (1988) Foundation Analysis and Design ( $4^{\text {th }}$ edn), McGraw Hill. 


\section{Civil Engineering Research Journal}

This work is licensed under Creative

Commons Attribution 4.0 License

DOI: $10.19080 / C E R J .2018 .03 .555620$
Your next submission with Juniper Publishers will reach you the below assets

- Quality Editorial service

- Swift Peer Review

- Reprints availability

- E-prints Service

- Manuscript Podcast for convenient understanding

- Global attainment for your research

- Manuscript accessibility in different formats

(Pdf, E-pub, Full Text, Audio)

- Unceasing customer service

Track the below URL for one-step submission https://juniperpublishers.com/online-submission.php 